\title{
Biodiversity of Upwelling Coastal Systems of the Southern Caribbean Sea Adjacent to Guajira Peninsula
}

\author{
Catalina Vasquez-Carrillo * and Kathleen Sullivan Sealey
}

check for updates

Citation: Vasquez-Carrillo, C.; Sullivan Sealey, K. Biodiversity of Upwelling Coastal Systems of the Southern Caribbean Sea Adjacent to Guajira Peninsula. J. Mar. Sci. Eng. 2021, 9, 846. https://doi.org/ $10.3390 /$ jmse 9080846

Academic Editor: Alen Soldo

Received: 7 June 2021

Accepted: 2 August 2021

Published: 5 August 2021

Publisher's Note: MDPI stays neutral with regard to jurisdictional claims in published maps and institutional affiliations.

Copyright: (c) 2021 by the authors. Licensee MDPI, Basel, Switzerland. This article is an open access article distributed under the terms and conditions of the Creative Commons Attribution (CC BY) license (https:/ / creativecommons.org/licenses/by/ $4.0 /)$.
Coastal Ecology Laboratory, Department of Biology, University of Miami, Coral Gables, FL 33146, USA; ksealey@miami.edu

* Correspondence: cvasquezcar@gmail.com

Abstract: This paper describes the unique natural communities and biodiversity of the upwelling coastal system along the Guajira peninsula in the southern Caribbean Sea. The Guajira peninsula has a small human population with limited infrastructure and limited opportunities for coastal research, yet its coastal upwelling system is unique in the Tropical Western Atlantic region. This report includes both field observations along with a review of literature on the biodiversity of coastal eastern Guajira. In addition, it identifies missing information on the coastal system that is key to its management and conservation. Mangrove wetlands along with submerged aquatic vegetation (SAV) communities in a combination of consolidated and unconsolidated shorelines (e.g., rocky shores, cliffs, and beaches) form unique habitats in eastern Guajira. The diversity of these habitats is illustrated with the Bahia Hondita marine lagoon, where critical nursery habitat for several commercial valuable and endangered fisheries species, including sharks and sea turtles, is observed. Less information is available on more cryptic fauna, invertebrates, and coastal plankton species. Several anthropogenic factors are threatening species diversity in coastal Guajira, including overgrazing, mining, and target-species overfishing. Additional threats, such as extreme weather events (e.g., storms and droughts) as well as changes in coastal water quality, are also impacting species. The protection of the Guajira's biodiversity would depend on local communities' governance and empowerment as well as law enforcement for mining and agriculture operations. Management plans can include reducing land-based sources of pollution and building coastal resilience for climate change.

Keywords: coastal biodiversity; Caribbean Sea; upwelling; mangroves; Guajira; Bahia Hondita; sea turtles

\section{Introduction}

The tropical Western Atlantic (TWA) province includes both an insular component (eastern Caribbean) and a continental component including portions of both Central and South America (central Caribbean). Ranging from the Gulf of Mexico to the Amazonian, there are six marine ecoregions within the TWA province, including the Central Caribbean ecoregion [1]. The Central Caribbean ecoregion is biologically diverse, including large coastal ecosystems, such as river deltas and estuaries, mangrove forests, coral reefs, seagrass beds, and upwelling areas [2-4]. Within this ecoregion, coastal species richness tends to concentrate both along the Antillean arc (Cuba to the southernmost Antilles) and the northern coast of South America (Venezuela-Colombia) [3]. Connected to the large biodiversity in the coasts of Venezuela and Colombia is the occurrence of a yearly coastal upwelling system, the Southern Caribbean Upwelling System (SCUS), which provides nutrients that power primary productivity [5]. The SCUS is probably the main source of the nutrients that support biological productivity in the oligotrophic Caribbean Sea and constitutes a priority coastal system for research and conservation of biodiversity in the TWA [2,5]. This ecoregion, however, has high human coastal population densities, a long history of anthropogenic pressure upon its marine resources, and significant levels of land and water pollution [3,6-8]. Pollution and marine resource exploitation have caused 
ecosystems' degradation, the endangerment of species, and the loss of habitat. These anthropogenic activities are associated with the primary economic activities of the ecoregion, particularly in the southern portion by the coastlines of Colombia and Venezuela, such as oil extraction, port development and tourism, and agriculture, among others [6,9].

The Guajira peninsula in northeast Colombia protrudes into the southern Caribbean Sea and is part of the SCUS (Figure 1). Therefore, Guajira's waters have elevated levels of nutrients that support the growth of diverse primary producers and the flow of biomass in marine food webs [10]. The Guajira's upwelling ecosystem consists of more than 960 species interrelated in complex flows of energy and matter [10]. The biodiversity of Guajira supports active commercial and artisanal fisheries upon which human coastal communities depend [11-13]. Despite the biological, social, and economic importance to Colombia and the local communities of Guajira's biodiversity, several factors have hindered the performance of adequate scientific studies from knowing, understanding, and protecting this biodiversity [13]. The northeastern or upper region is a dry and hot desertlike land, with impressively high sand dunes and scarce xerophytic vegetation, high winds, and low precipitation [11]. As a result of the harsh weather conditions, upper Guajira has a low population and is rural, with traditional economic activities related to natural resources exploitation, particularly fishing [11]. Other economic activities are cattle raising and agriculture. However, they have generally failed in recent years due to prolonged drought [14]. Transportation or communication infrastructures are scarce, as well as basic services, such as electricity and clean water [15]. The lack of services in and connectivity to upper Guajira, along with other socioeconomic factors, cause its coastal ecosystems to remain "hidden" from the rest of the peninsula and from the world. Therefore, the unique and high diversity of coastal Guajira and its habitats remains to be assessed. This review explores the current knowledge on the coastal and marine biodiversity of the upper Guajira region at all levels (ecosystems, species, and genetics) to identify the gaps in their ecological knowledge and point out ways to obtain this knowledge. Additionally, this review intends to highlight what are the threats that coastal biodiversity in Guajira is or may be facing in the near future, and what are the measures to protect or conserve this biodiversity.

The coast of the Guajira peninsula is a species-rich, ecologically complex area in Colombia, southern Caribbean Sea, with a remarkable diversity of marine natural communities [10,16-18]. However, this biodiversity is still far from fully known and classified. Current descriptions of these marine communities do not generally follow ecologically meaningful classification standards that allow to identify, describe, map, and quantify these communities and their habitats better [19]. Here we followed the Coastal and Marine Ecological Classification Standard (CMECS) (2012) to name and begin describing the unique diversity of marine natural communities that constitute habitat for many species of ecological, cultural, economic value in northeastern Guajira. The standard provides a common vocabulary to name and describe biotopes, that are unique to given areas, by allowing the inclusion of the geographic and geologic settings and the substrate and biotic components present in those areas to the descriptions [19]. Furthermore, we used the concept of biotope to describe the diversity of natural communities of Guajira ecologically due to the many combinations of species assemblages and specific environmental conditions occurring in the study area. We used the marine lagoon of Bahia Hondita as a study case of coastal biotope diversity in Guajira. 


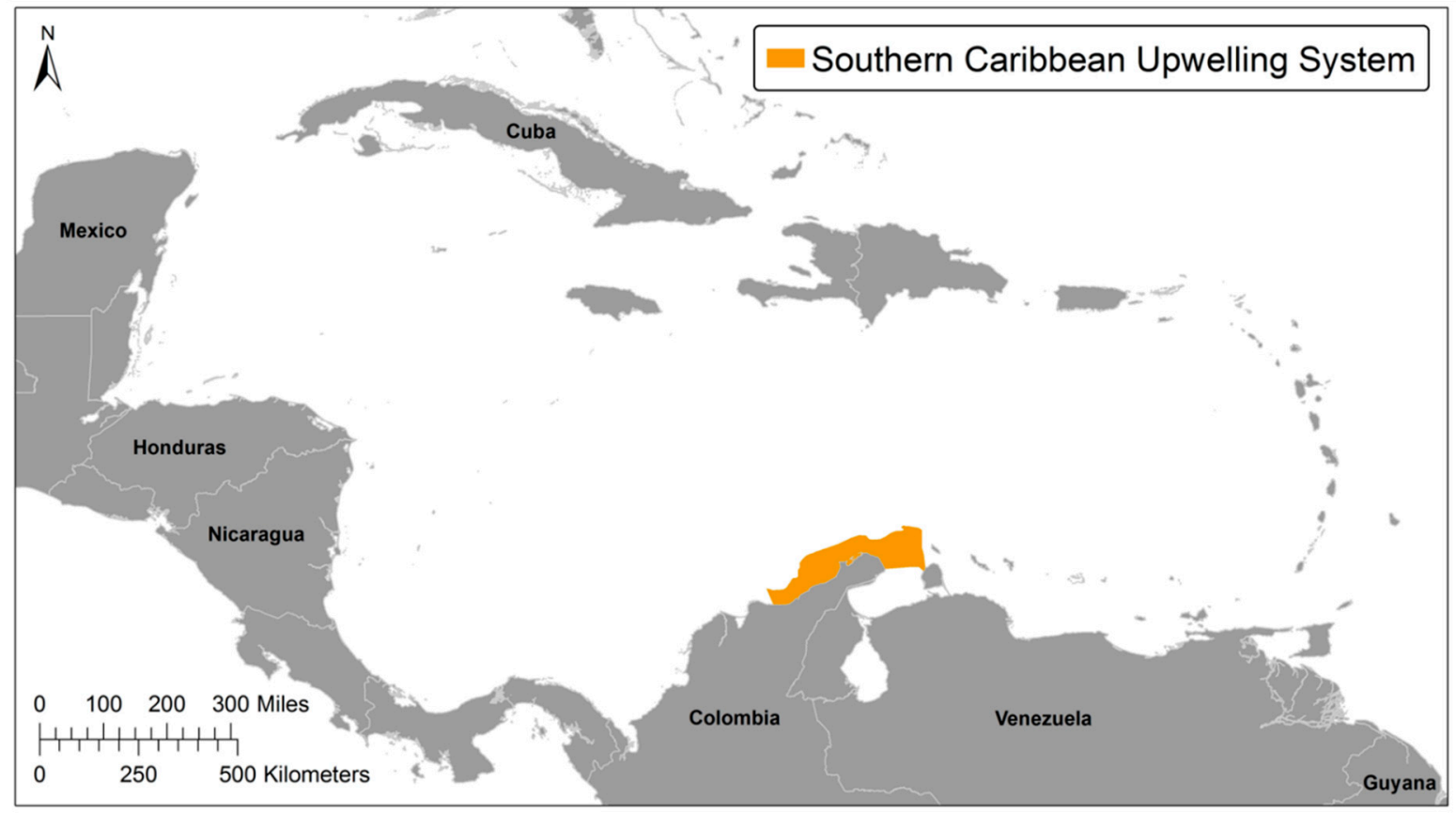

Figure 1. Southern Caribbean Upwelling System by the Colombian peninsula of La Guajira (in orange) $\left(10-12.5^{\circ} \mathrm{N}\right.$ $\left.63-65^{\circ} \mathrm{W}\right)$ in the Central Caribbean Ecoregion $\left(14^{\circ} 31^{\prime} 19^{\prime \prime} \mathrm{N},-75^{\circ} 49^{\prime} 3^{\prime \prime} \mathrm{W}\right)$ of the Tropical Western Atlantic.

\section{The Biodiversity of Coastal Guajira}

\subsection{Biotope Diversity}

Multiple biotopes in the Nearshore Marine Regime of the northeastern Guajira peninsula are described here (Table 1, Figure 2). Aside from the open ocean side typical of a peninsula, this regime includes other coastline formations, such as marine lagoons (or embayments) [11]. Within each coastline formation, assemblages of biodiversity concentrate in different zones. The zones included in this review are the bottom (or seafloor), the shoreline, and the water column (Table 1). In the water column zone, only a few biotopes were identified on both embayments and the open ocean side because little information is available on the biotic communities living and conforming to these habitats. Therefore, they were described based only on physical characteristics, such as depth, salinity, and turbidity. For instance, in the water column zone of the marine lagoon of Bahia Hondita, the water column has low depth (1-5 m deep), high or extremely high salinity ( $>38 \mathrm{ppt}$ ), and high turbidity, which defined two biotopes, (1) Ephemeral hypersaline marine lagoon with a dry season due to evaporation and (2) Saline lagoon with a narrow opening to the coastal ocean. Most of Guajira's biotopes described here are found in the benthic zone, which includes soft and hard bottoms $[11,20]$. Soft bottoms are mineral muds and sands or biogenic (mollusks shells) sands $[18,20]$. Hard bottoms are mineral cobbles and pebbles. Attached to these bottoms, partially or totally covered by water, are different taxonomic groups of benthic submerged aquatic vegetation (SAV), forming a wide diversity of biotic communities and defining the biotopes described in Table $1[18,21]$. SAV communities of Guajira's platform include seagrass or macroalgae or mixed seagrass-macroalgae meadows $[17,18,21,22]$. Common SAV communities observed in eastern upper Guajira are Thalassia testudinum beds and Gracilaria sp. (Rhodophyta) beds [21,22]. These meadows are observed close to shore, in shallow, murky open ocean side waters, or in association with mangrove forests in marine lagoons. Other biotopes are observed in the shoreline zone of lagoon and open ocean side formations (Table 1). In the marine lagoon of Bahia Hondita, northern upper Guajira, mangrove vegetated shorelines are common and diverse (Figure 3). Three species of mangrove form woodlands, scrublands, and shrub thickets, the most common of which is the red (R. mangle), followed by black (Avicennia germinans), and white (Laguncularia racemosa) mangroves (Table 1, Figure 3). These mangrove communities differ in configuration. Common mangrove communities' configurations in 
Bahia Hondita are fringing, overwash, inverted, and or basin mangroves. Mangroves are found in mudflats, sandy barns, channels, and basins and in close association with SAV beds. In addition to mangrove shorelines, vegetated and unvegetated rocky shores are observed on both marine lagoons and the open ocean side (Table 1) [11]. Some of these rocky shores occur in close proximity to sandy beaches and mangrove communities. In addition, several sandy shoreline biotopes are common on the open ocean side of eastern Guajira (Table 1) [11,23]. There are vegetated or unvegetated sandy beaches, dunes, and back beach swales. The grain of these sandy shorelines is biogenic, from mollusk shells, coarse (sand), or fine (sandy muds) $[11,20]$. Some of the sandy beaches are long and narrow (by Santa Cruz fishing port) or short and narrow embedded in pockets within rocky shores, often called pocket beaches (Bahia Hondita lagoon). These sandy shores are quite unique in their geomorphology, in Guajira, Colombia $[11,20]$.

Table 1. Diversity of biotopes in the nearshore marine regime of coastal northeastern Guajira according to the CMECS classification standard (2012).

\begin{tabular}{|c|c|c|c|}
\hline Formation & Zone & Macrohabitat & Biotope (or Natural Community) \\
\hline \multirow{13}{*}{$\begin{array}{l}\text { A.01. Marine } \\
\text { lagoon }\end{array}$} & \multirow[t]{13}{*}{ Water Column } & Hypersaline (> $38 \mathrm{ppt}$ ) shallow water & $\begin{array}{c}\text { Ephemeral hypersaline lagoon, dry season due } \\
\text { to evaporation }\end{array}$ \\
\hline & & $\begin{array}{l}\text { Saline (34-38 ppt) coastal embayment } \\
\text { connected to coastal ocean }\end{array}$ & $\begin{array}{l}\text { Saline lagoon with a narrow opening to coastal } \\
\text { ocean }\end{array}$ \\
\hline & & Unvegetated hardbottom $>$ rocky & $\begin{array}{l}\text { Large boulders and angular rocky dominate } \\
\text { the bottom. No notable SAV and high turbidity }\end{array}$ \\
\hline & & Vegetated hardbottom $>$ rocky & $\begin{array}{l}\text { Small rocks bottom with some macroalgae on } \\
\text { the rocks, and some macroalgae between rocks }\end{array}$ \\
\hline & & Unvegetated softbottom $>$ mud & $\begin{array}{l}\text { Shallow muddy softbottom with high turbidity, } \\
\text { no SAV, dominated by bivalves }\end{array}$ \\
\hline & & Unvegetated softbottom $>$ sand & $\begin{array}{c}\text { Intertidal to a very shallow sandy bottom, } \\
\text { exposed at low tides }\end{array}$ \\
\hline & & Unvegetated softbottom $>$ sand & $\begin{array}{c}\text { Intertidal to a very shallow biogenic (shell) } \\
\text { sandy bottom, near mangroves, exposed at low } \\
\text { tides }\end{array}$ \\
\hline & & Vegetated softbottom $>$ mud, sand & $\begin{array}{c}\text { Nearshore shallow sparse Thalassia testudinum } \\
\text { biogenic (shells) sandy bottom }\end{array}$ \\
\hline & & Vegetated softbottom $>$ mud, sand & $\begin{array}{l}\text { Nearshore shallow sparse mixed } \\
\text { seagrass-macroalgae vegetated bottom }\end{array}$ \\
\hline & & Vegetated softbottom $>$ mud, sand & $\begin{array}{c}\text { Nearshore shallow, moderate to dense mixed T. } \\
\text { testudinum-Syringodium filiforme-Halodule } \\
\text { wrightii vegetated bottom }\end{array}$ \\
\hline & & Vegetated softbottom $>$ mud, sand & $\begin{array}{c}\text { Nearshore shallow, moderate to dense } T \text {. } \\
\text { testudinum vegetated bottom }\end{array}$ \\
\hline & & Vegetated softbottom $>$ mud, sand, shells & $\begin{array}{l}\text { Nearshore moderate to dense mixed } \\
\text { seagrass-macroalgae vegetated bottom and } \\
\text { high turbidity }\end{array}$ \\
\hline & & Vegetated softbottom $>$ mud, sand, shells & $\begin{array}{l}\text { Nearshore moderate to dense mixed } T \text {. } \\
\text { testudinum-S. filiforme-H. wrightii vegetated } \\
\text { bottom and high-water turbidity }\end{array}$ \\
\hline
\end{tabular}


Table 1. Cont.

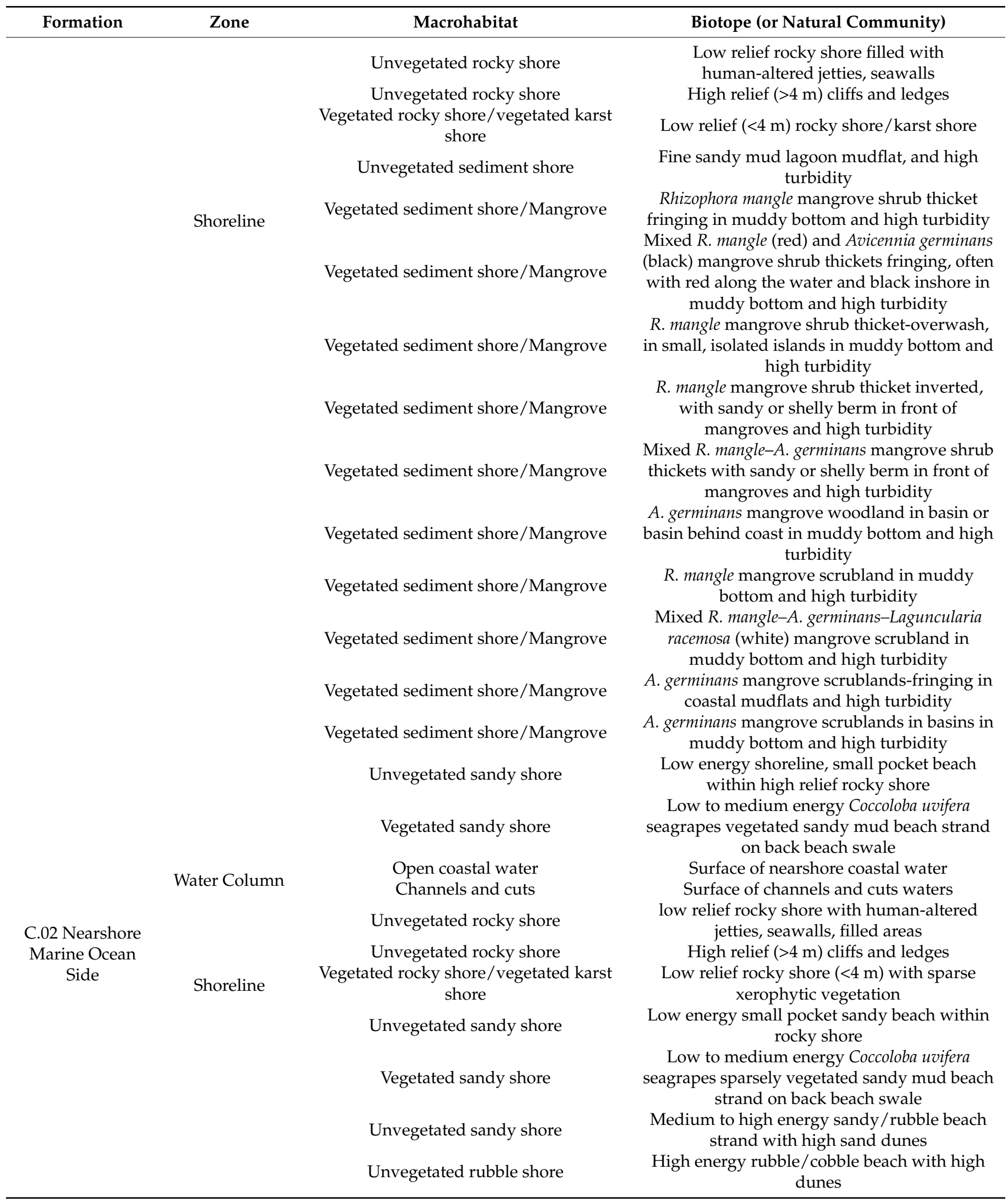



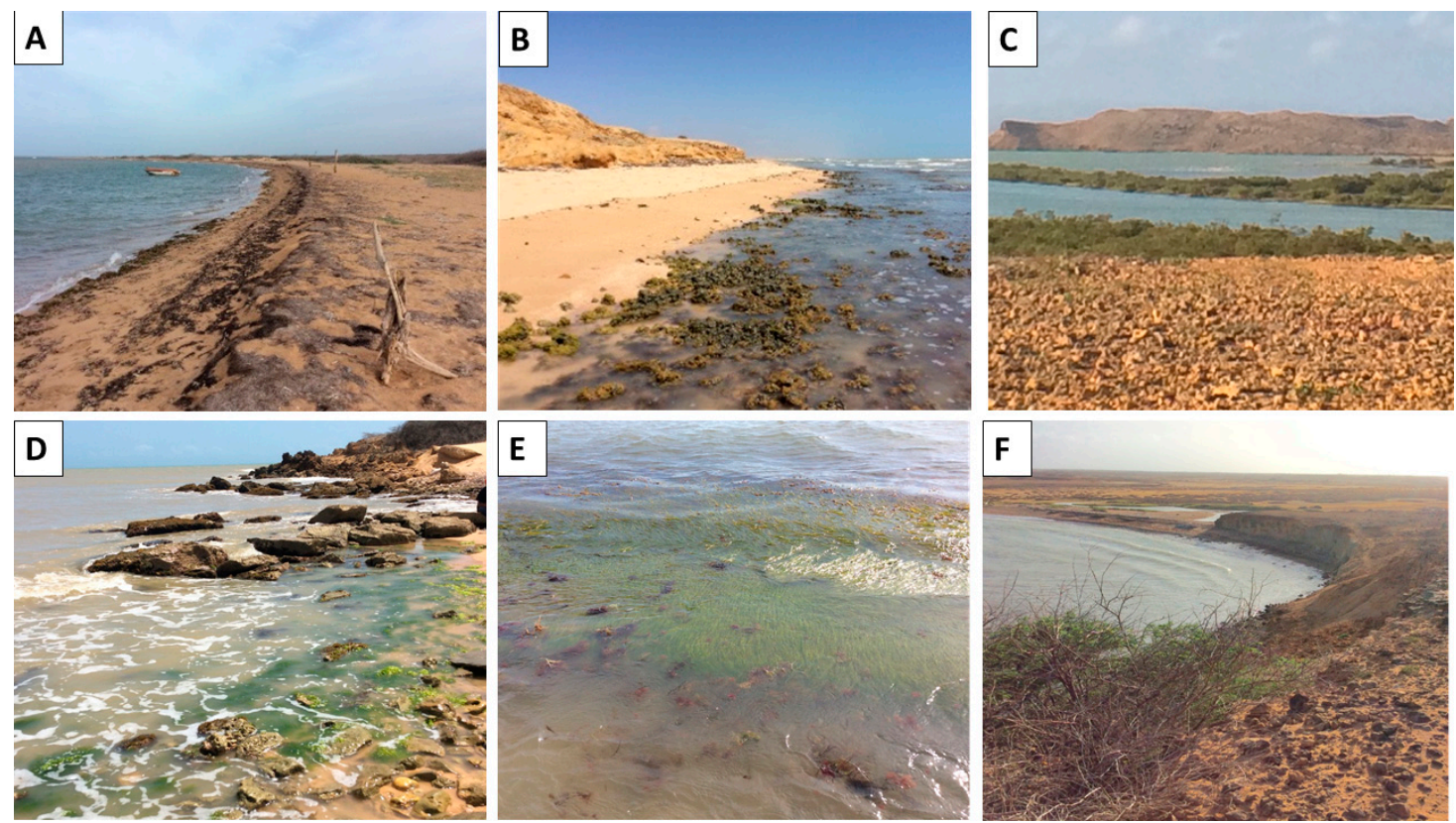

Figure 2. Example biotopes (natural communities in two formations of the nearshore marine regime, in the northeastern Guajira peninsula. Open ocean side formation: (A). Unvegetated sandy beach shoreline in open ocean side formation. (B). Nearshore shallow macroalgae meadow.; (D). Macroalgae vegetated rocky shoreline. (E). Nearshore mixed seagrass meadow. (F). Rocky cliff shoreline. Marine lagoon formation: (C). Mangrove vegetated shoreline.

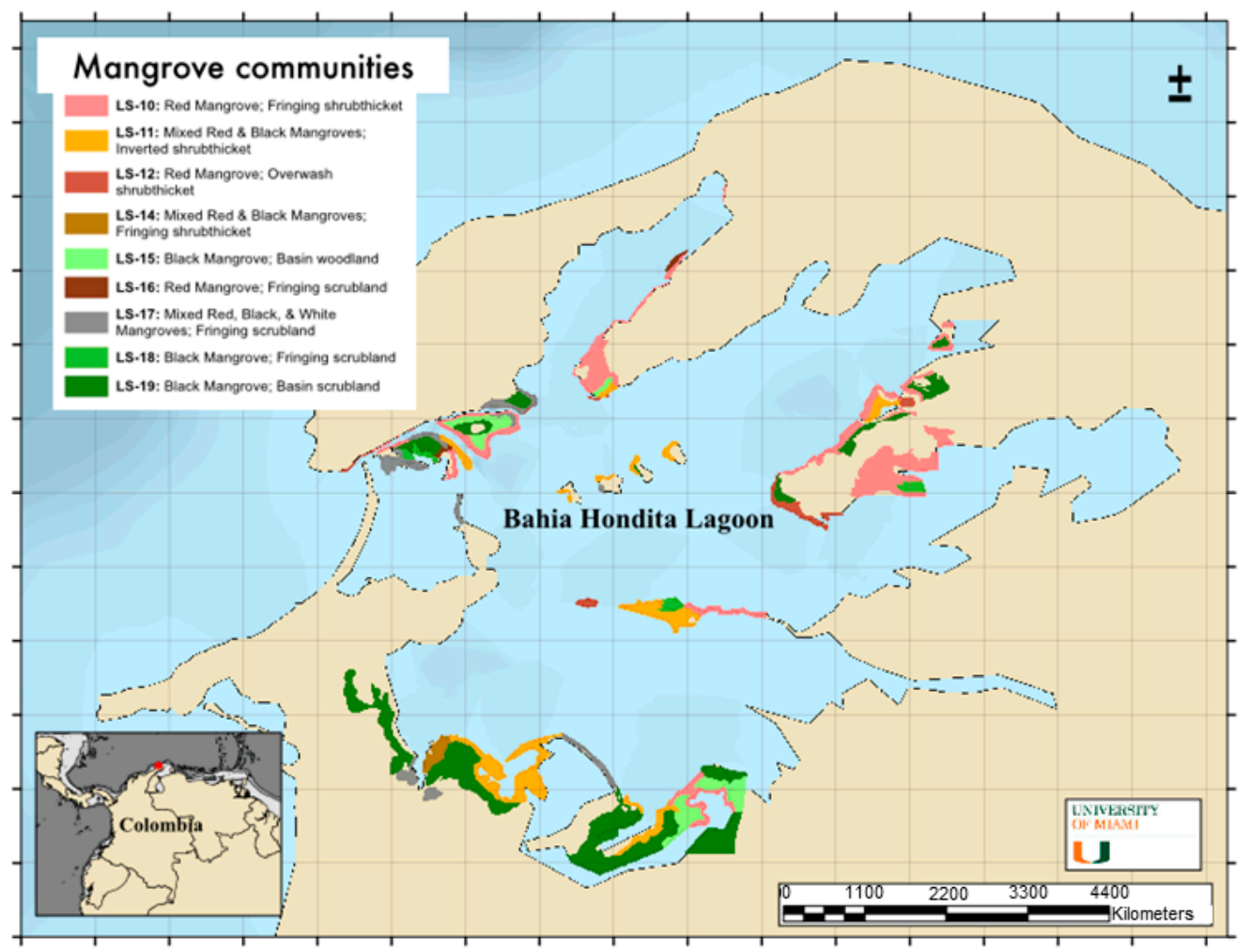

Figure 3. Map of the diverse mangrove shoreline biotopes of the Bahia Hondita marine lagoon $\left(12.403^{\circ} \mathrm{N}, 71.695^{\circ} \mathrm{W}\right)$, northeastern Guajira. Map was created from Google Earth Images and ground-truthing of location points from 2016, using ArcGIS (Esri, 2012). 


\subsection{Species Diversity of Eastern Guajira}

Several species of cultural, economic, and ecological importance occupy or use the nearshore marine biotopes of eastern Guajira for habitat (Table 2, Figures 4 and 5). It is estimated that more than 900 species are part of the Southern Caribbean upwelling system by La Guajira, 149 of which are marine macroalgae (Macrophyta) [10,24]. However, fifty more species of marine macroalgae have been reported for the eastern Guajira alone recently, and more species are expected to be found in this area if sampling power and range increase [21] (Figure 4). Macroalgae is the most diverse group of marine plants in Colombia [5]. Among Guajira's macroalgae groups, the red algae (Rhodophyta) are the most abundant and diverse [21,22]. Within this group, species of Gracilaria sp. are particularly prominent, specious, and extensive throughout the coastline of eastern Guajira (Figure 4). As a result of macroalgae diversity, eastern Guajira has been pointed out as a hotspot of marine plant biodiversity in the Caribbean Sea [21]. Another group of high diversity and ecological importance for Guajira habitats are aquatic birds, with about 87 species, including the exotic and vulnerable species of American flamingo (Phoenicopterus ruber) [25]. Several of these birds inhabit the desertic upper Guajira (Figure 5). For instance, American flamingoes, egrets, herons, and pelicans, which are found in close association with the mangrove shorelines of the Bahia Hondita lagoon [25]. A third prominent group in terms of species diversity in northeastern Guajira is marine turtles (Reptilia: Testudines). Four of the seven extant species of this group either reside, forage, or nest in the area (Table 2, Figure 5) $[13,23,26]$. Guajira's nearshore biotopes are a particularly suitable habitat for foraging and nursing of juvenile-staged green sea turtles (Chelonia mydas) [27]. These habitats may be suitable for nursing juvenile cartilaginous fish (sharks and rays) of several species in Guajira's waters [28]. No studies or reports were found for other taxonomic groups representative of marine biodiversity in eastern Guajira (Table 2). These groups include phytoplankton and zooplankton species, which are expected to be abundant due to the unique upwelling characteristics of Guajira's coastal system [29]. More than 77 species of phytoplankton occur throughout the continental platform of western and central Guajira, but the number of species for the eastern side is unknown [29]. Other groups with no information for eastern Guajira are sponges and echinoderms. These taxonomic groups have been observed in other areas of the peninsula, therefore, are expected to be found in eastern Guajira $[18,25,30]$. Future research on eastern Guajira's species diversity should focus on baseline species identification, habitat mapping, and estimation of richness and diversity for the taxonomic groups for which no information is available. Furthermore, ecological studies on subspecies, growth rates, mortality and survival rates, and life-history traits of the species specific to Guajira's environmental conditions are necessary to increase the knowledge of the area's biodiversity.

Table 2. Species diversity estimates in eastern Guajira by taxonomic group.

\begin{tabular}{cccc}
\hline Group & Number of Species & Species Expected & Reference \\
\hline Phytoplankton & Unknown & yes & NA \\
Zooplankton & Unknown & yes & NA \\
Seagrasses & 3 & yes & {$[21]$} \\
Macroalgae & 113 & yes & {$[31]$} \\
Sponges & Unknown & yes & {$[13,32]$} \\
Bony fish & 25 & yes & {$[13]$} \\
Cartilaginous fish & 15 & yes & {$[13]$} \\
Mollusks and & 1 & yes & {$[13]$} \\
Crustaceans & 4 & no & NA \\
Marine reptiles & Unknown & no & NA \\
Seabirds and flamingoes & 0 & yes & NA \\
Corals and jellyfish & Unknown & yes & NA \\
Echinoderms & Unknown & &
\end{tabular}

NA: Not available. 

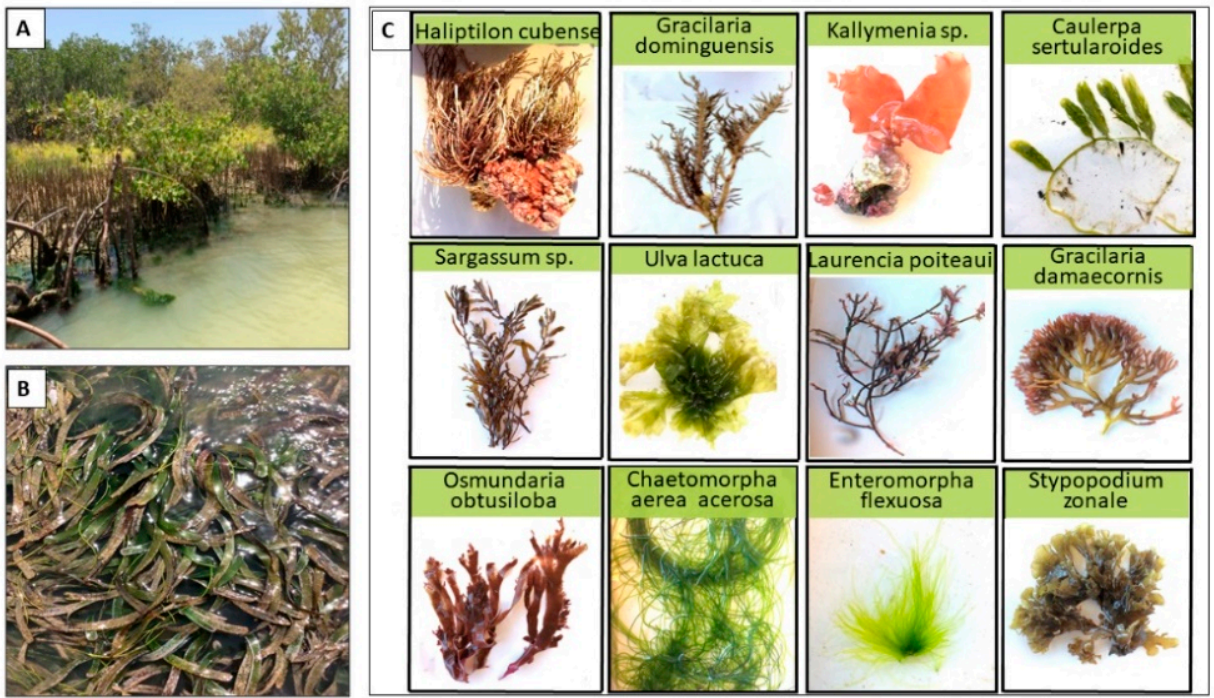

Figure 4. Examples of the diversity of marine plants of coastal eastern Guajira. (A): Mangrove trees Rhizophora mangle and Avicennia germinans; (B): Seagrasses Thalassia testudinum and Syringodium filiforme; (C): Macroalgae, including three species of red algae Gracilaria.

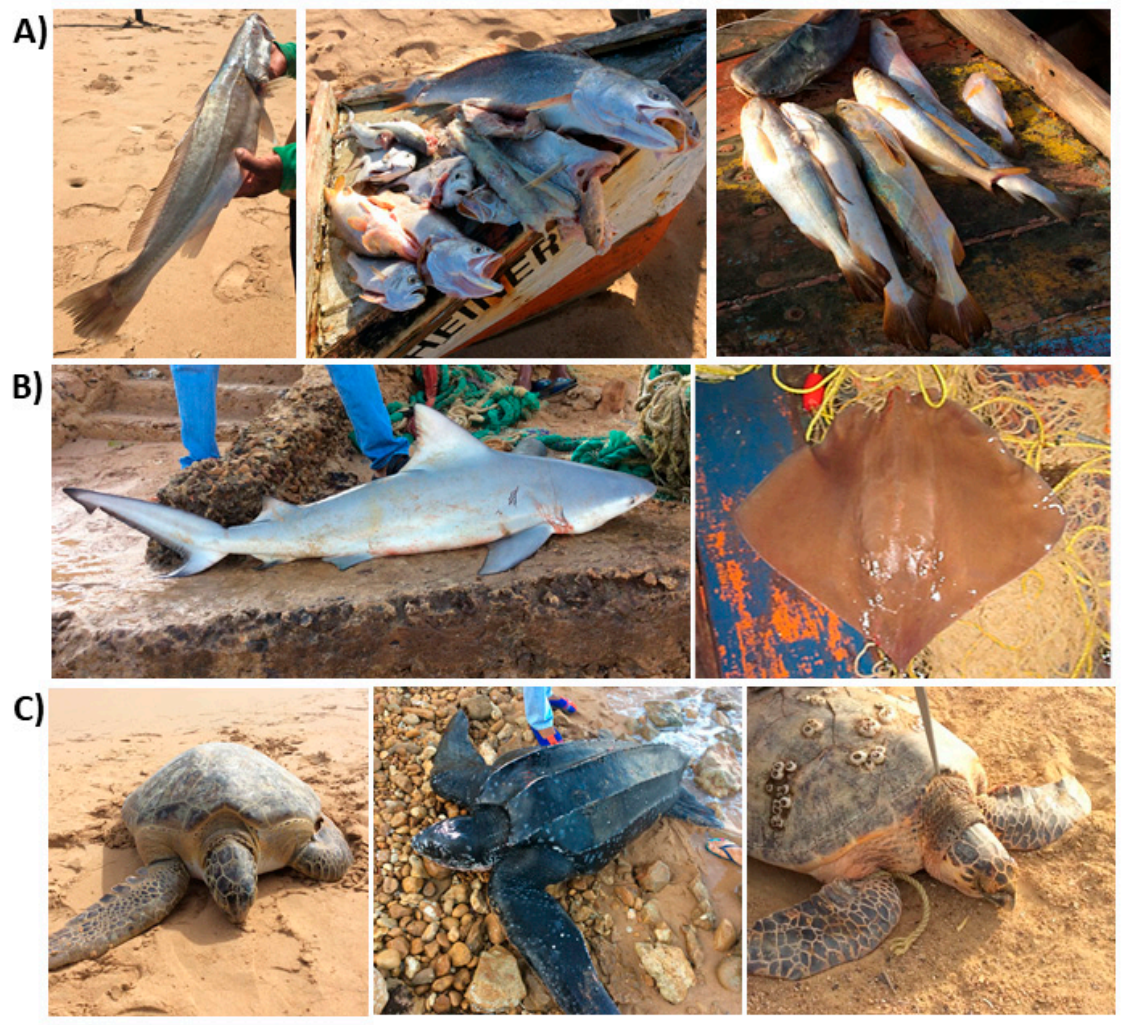

Figure 5. Marine animal species diversity of coastal eastern Guajira. (A). Commercial finfish (right: Cynoscion sp., and Rachycentron canadum). (B). Cartilaginous fish (left: Carcharhinus perezi; right: Dasyatis guttata). (C). Marine turtles (left: Chelonia mydas; middle: Dermochelys coriacea; right: Eretmochelys imbricata).

\subsection{Genetic Diversity}

A few studies of Guajira's biodiversity have assessed and quantified the genetic diversity among and/or within populations of a species or relate this diversity to the habitat conditions of the area. For example, one study measured the genetic diversity at the nucleotide level of the control region of the mitochondrial DNA (mtDNA) of green 
sea turtles [27]. The sea turtle's genetic diversity was high [27]. Sea turtles coming from multiple, geographically separated, nesting rookeries groups contribute to the genetic diversity of the Guajira populations. These turtles may be arriving from both the central and southern eastern Atlantic as well as from the eastern Atlantic nesting rookeries using opposite direction, current systems [27]. Like sea turtles, another charismatic but vulnerable species for which genetic studies have been performed is the Caribbean sharpnose shark Rhizoprionodon porosus [33,34]. This shark is common in eastern Guajira, particularly in the juvenile stage, and it utilizes its coastal waters for nursery [35]. Although no genetic studies have been performed on R. porosus from eastern Guajira, the ones performed in western or lower Guajira sharks indicate that they are genetically distinct from sharks of the rest of the Colombian Caribbean [33]. Lastly, two cosatal middle-sized Haemulidae fish of local economic importance to artisanal fisheries have also been studied for their genetic diversity [36]. The Guajira populations of Haemulon aurolineatum and H. steindachneri fish showed elevated levels of heterozygosity measured with microsatellite DNA markers and were different from other populations in the southern Caribbean Sea.

Overall, the genetic studies with turtles, fish, and sharks show that Guajira's coastal upwelling system harbors significant levels of genetic diversity and differentiation, which may be explained by its unique oceanographic and ecological conditions. These conditions may cause restrictions to gene flow between populations or subpopulations and local adaption to these conditions (reflected in the genome). Population genetic studies in other key taxonomic groups are needed to reveal trends in the distribution of genetic diversity of Guajira and its connectivity to other areas in the Greater Caribbean region. Examples of taxonomic or functional groups to survey for are macrophytes (e.g., macroalgae and seagrasses), which are at the base of food webs and are specious in Guajira. Migratory species using Guajira as a stopover or reproductive habitat, such as marine birds, are also important to survey. Comparison of genetic patterns between taxonomic groups can bring light to the importance of seascape variables in structuring the genetic diversity of populations and species in the SCUS and the entire Central Caribbean ecoregion [37].

\section{Unique Environments That Support Guajira's Biodiversity}

Several ecological and seascape factors have been postulated to support marine biodiversity. From these factors, we chose three we considered key in supporting the unique genetic, species, and biotope diversity in the Guajira peninsula. (1) food abundance and diversity due to nutrient enrichment; (2) unique sea bottom configurations; and (3) low anthropogenic disturbance to coastal environments.

\subsection{Nutrient Enriched Waters}

Guajira peninsula waters are one epicenter for nutrient enrichment from the coastal upwelling occurring every year between the months of January and May in the Southern Caribbean $[5,38]$. The enrichment is triggered by the action of the Trade Winds causing upwelling of subsurface waters. The colder waters of the subsurface have greater amounts of nutrients, such as nitrogen and phosphorus, than the warmer oligotrophic surface waters of other areas in the Caribbean Sea [39-41]. The excess and diverse nutrients stimulate the growth and the productivity of phytoplankton at the base of the marine food webs, and thus the flow of biomass and energy upwards the web [42]. Greater primary productivity also increases species richness in ecosystems [43]. Diverse marine ecosystems, such as the one at Guajira, support productive fisheries for human sustenance [38-44]. The most productive (high biomass or species diversity) fisheries of the world occur in upwelled coastal areas [45]. Algae is responsible for most of the primary production in oceans. The seasonal variation in upwelling conditions in the Colombian Caribbean Sea contributes to differences in the structure and species composition of macroalgal assemblages [24]. Macroalgae assemblages are prolific and diverse in eastern Guajira [18,21]. The abundance and diversity of these primary producers may attract a suite of primary consumers in multiple life stages (e.g., juvenile, adults), which, in turn, serve as food for consumers in 
upper levels of food webs. For instance, populations of juvenile green sea turtles in Guajira are found in close association to nearshore, macroalgae, and seagrass meadows, where they are feeding; juvenile sea turtles are food for sharks [21,26]. The greater biomass or nutrition of food resources in upwelled ecosystems may cause faster growth rates which may contribute to greater survival of resident juvenile sea turtles until they migrate for reproduction to other habitats outside of Guajira. Similarly, other large, threatened, or economically important species are associate with the vegetated benthic communities and shorelines of Guajira and may take advantage of its diverse nutrient-rich food resources offered [18].

\subsection{Complex Structure Seafloors}

Habitat is not only the place where food resources for a given species are present but where the requirements to complete part or the whole of its life cycle, that is, to survive, develop, migrate, and reproduce, are met. A species habitat is expected to contribute to the dynamics of populations by providing the conditions for high survival rates or low mortality rates and high fertility rates $[46,47]$. Quality habitats should provide enough resources (e.g., food) but also have structural complexity to allow individuals of a species to escape or take refuge from predation-thus reducing mortality rates, and to nest, nurse and/or mate, thus increasing fertility or reproductive rates. Guajira's coastal habitats' bottom configuration and characteristics are unique in the Caribbean Sea [21]. They seem particularly suitable for nursing juvenile stages of several species of marine fish and megafauna [21]. Several Guajira's benthic communities are mixed, vegetated with mineral boulders and cobbles or pebbles (Table 1) [18]. These vegetated rocky biotopes offer places for refuge from predators, resting, as well as vegetation that serves as food. Having multiple requirements for survival in one place decreases the need to allocate energy on dispersal to escape from predators or foraging after hiding or resting from predation, and this energy can be allocated to growth and development instead. Here we propose eastern Guajira's benthic structural complexity as one of the factors supporting the biodiversity observed in the area and illustrate this hypothesis with the case of the green sea turtle nurse habitats in eastern Guajira.

The green sea turtle's life cycle starts as an egg in sandy beaches, the nesting habitat, and continues into the early juvenile stage at the surface of gyres and eddies in (the early juvenile habitat) until neritic habitats near coastal areas (the juvenile developmental habitats) are reached $[48,49]$. Developmental habitats are key to the dynamics of juvenile populations because survival at these habitats guarantees attainment of the reproductive stage [47]. Juvenile and subadult turtles are typically found at nearshore coastal waters with seagrasses and macroalgae meadows which they use for food, but also with structures such as coral reefs or rocky benthic communities [50,51]. Sea turtles utilize the outcrops and stony caverns of coral reefs and rocky benthic communities as sleeping areas and refuge areas from predators [50,51]. More juvenile turtles are observed in areas where aquatic vegetation meadows and rocky outcrops or reefs and caverns are in proximity or are intermixed than in areas where these two are far apart. The sea bottoms in Guajira are muddy sands and sands with cobbles and boulders [11,52]. These rocks may accomplish the role of refuge sites from predators that corals play in other areas of the distribution range of the species. In addition, the rocks and bottoms in this area are covered with aquatic vegetation that marine turtles feed upon. Therefore, the turtles do not have to spend energy dispersing between feeding and resting areas, optimizing their energy expenditure. The excess of energy may be devoted to growth, for instance, in body mass, as opposed to dispersal. Juvenile or larvae of other species, such as shark species, are abundant in coastal Guajira (e.g., Rhizoprionodon sp.). The diversity and seafloor complexity of Guajira biotopes may contribute to the population dynamics of these species. 


\subsection{Low Anthropogenic Disturbance Seashores}

Coastal areas are among the most populated and developed places around the globe. As such, they are subject to profound anthropogenic disturbances, such as shoreline erosion, pollution, tourism, boat traffic, building construction, etc. [8,53]. These disturbances profoundly change the landscape and physical characteristics of both land and water and negatively impact marine biodiversity through increasing mortality rates, decreasing fertility rates, etc. [54,55]. Some negative impacts associated with coastline conversion and disturbance are habitat loss and degradation, species reductions and loss, genetic diversity loss, and pollution $[8,9,55,56]$. The coasts of eastern Guajira have been spared from several of these impacts because of the small human populations living in these areas, low development, and lack of infrastructure construction, low to no tourism, and low boat traffic. Instead, these coasts remain somewhat "pristine" as they are isolated from disturbance, at least in the land portion of shorelines. Low disturbance of benthic marine habitats, such as seagrass meadows or mangrove forests, guarantees biodiversity feeding, nursing, and residency areas [57], increases survival rates, and increases biodiversity as more species are attracted to the resources available. However, the biodiversity of coastal eastern Guajira does experience some anthropogenic threats from current or past events to consider when studying its habitats (Table 3, Section 4). Most of these threats are contextual and refer to land-based activities occurring in the rest of the peninsula, such as mining, overgrazing, and fishing pressure, as well as global factors, such as climate change. Understanding these threats can contribute to better management and conservation of Guajira's biodiversity.

Table 3. Threats to the coastal biological diversity of the Guajira peninsula from El Cabo to the Venezuela border. This represents about $370 \mathrm{~km}$ of shoreline, including embayments. The coastal marine ecosystems include coastal mangrove wetlands, seagrass meadows, soft bottom communities, and algal beds.

\begin{tabular}{|c|c|c|c|c|}
\hline Category & Specifics of Threat & Low & Med & High \\
\hline 1. Development & $\begin{array}{l}\text { Small population centers, no large cities, but some areas } \\
\text { are vulnerable to migration of people from Venezuela into } \\
\text { Colombia. The largest city in the region, Riohacha, is } \\
\text { considered a key point of entry and supply to La Guajira, } \\
\text { but limited tourism outside this city. }\end{array}$ & $X$ & & \\
\hline 2. Agriculture and Farming & $\begin{array}{c}\text { The area is arid, and with climate change, conditions will } \\
\text { be warmer and drier. Water is imported for cattle, and } \\
\text { some reservoirs have been built. Over-grazing by goats } \\
\text { and cattle is a serious threat to coastal natural } \\
\text { communities. }\end{array}$ & & $x$ & \\
\hline
\end{tabular}

Mining of coal via an open pit mine is a large operation in the area but impacts in coastal environments are unknown. Sea turtles display fibropapilloma (FP), which indicates heavy metals pollution in benthic environments. Heavy metals are used in coal mining operations, but the link to sea turtles FP has not been proved.

\begin{tabular}{|c|c|c|}
\hline $\begin{array}{l}\text { 4. Transportation and Service } \\
\text { corridors }\end{array}$ & $\begin{array}{l}\text { Rail tracks and port for the export of coal create a threat to } \\
\text { marine communities in the westernmost Bahia. A large } \\
\text { port was built for the export of coal from the region }\end{array}$ & $X$ \\
\hline $\begin{array}{l}\text { 5. Biological resource use and } \\
\text { harm including within protected } \\
\text { areas }\end{array}$ & $\begin{array}{l}\text { Fishing regulations are poorly enforced. Sea turtles and } \\
\text { sharks are targeted as high-value target species. Most } \\
\text { species are for subsistence and consumed locally. Trawl } \\
\text { fisheries in the area have resulted in the collapse of some } \\
\text { fish populations. }\end{array}$ & $X$ \\
\hline
\end{tabular}


Table 3. Cont.

\begin{tabular}{|c|c|c|c|c|}
\hline Category & Specifics of Threat & Low & Med & High \\
\hline $\begin{array}{l}\text { 6. Human intrusion and } \\
\text { disturbance within protected } \\
\text { area }\end{array}$ & $\begin{array}{l}\text { There is one national park that includes culturally } \\
\text { important dunes and landforms. The park is managed by } \\
\text { the park service and protected. }\end{array}$ & $X$ & & \\
\hline
\end{tabular}

In the marine environment, the abundance of species has been altered by an extant commercial fishery that closed at the end of the 20th century. Many fish stocks were locally

overfished. It is unknown what damage the trawling

7. Natural systems modification might have done to benthic communities. Fishing now is largely for subsistence. Much of the coastal area has been altered by over-grazing. The entire region has experienced desertification with drought and loss of vegetation cover. Many small communities have lost their goats, and cattle are maintained with imported water.

8. Invasive and other
problematic species and genes

Little is known about invasive species in the coastal and marine environments. Few projects have surveyed the entire extent of the coastal ecosystems.

Little pollution monitoring; pollution loading unknown except for sediment and erosion into coastal waters with heavy rains. Coastal desertification and loss of vegetation can result in higher sedimentation rates in the future. Rancheria river waters charged with pollutants from mining and human populations waste may discharge generated within the areas

pollution into the ocean nearby Riohacha and other urban areas along the river.

\begin{tabular}{ccc}
\hline 10. Geological events & No known threats; earthquakes are a remote threat & $\mathbf{X}$ \\
\hline $\begin{array}{c}\text { 11. Climate change and severe } \\
\text { weather }\end{array}$ & $\begin{array}{c}\text { Area is suffering from long-term drought, and water is } \\
\text { extremely limited in the region. }\end{array}$ & $\mathbf{X}$ \\
\hline 12. Culture and social threats & $\begin{array}{c}\text { This is an indigenous area under the management of the } \\
\text { Wayuu communities. The environmental management of } \\
\text { the area is jeopardized by the high poverty and lack of } \\
\text { infrastructure in the indigenous communities. }\end{array}$ & $\mathbf{X}$ \\
\hline
\end{tabular}

\section{Threats to Guajira's Biodiversity}

We identified and described several anthropogenic factors currently threatening Guajira's coastal ecosystems, species, and fisheries in Table 3. These factors are classified according to the level of negative impact they may have on marine biodiversity from low to high. This ranking was subjective and given according to the amount or extent of the factor observed by the authors or referenced in the literature. Coastal development for infrastructure and tourism is a low threat in Guajira, particularly so in Upper Guajira. Only a few urban centers or cities are developed, including their coastal zones, with infrastructure, such as buildings, hotels, marinas, etc., for example, the coasts of the main city, Riohacha. Instead, the coasts in upper Guajira are poorly developed or not developed at all, for example, Puerto Estrella. Another category of low threat to coastal biodiversity in Guajira is invasive and other problematic species [58]. To our knowledge, only one invasive species of red algae (Kappaphycus alvarezzi) and one invasive species of fish, the lionfish (Pterois volitans), have been reported in Guajira waters [58]. No reports of the presence of these two species exist for eastern Guajira. The nature and extent of ecological impacts of these invasive species in Guajira remain unknown.

Another category of a threat of medium impact to local biodiversity is energy and coal mining $[59,60]$. A large open-pit coal mine operates in southeast Guajira, but no direct impacts to coastal biodiversity from this operation are known yet. However, mining operations are known to affect benthic ecosystems, their flora and fauna, through the disposal of chemical pollutants used [59,60]. Mining coal utilizes chemicals, such as heavy 
metals, that are retained in sediments and bioaccumulate and biomagnify in the food web [61]. Heavy metals in high concentrations have been found in the coastal ecosystems of Riohacha [62]. Furthermore, there is indirect evidence of the presence of heavy metals in Guajira's coastal waters with the presence of fibropapilloma tumors throughout the soft parts of the body of sea turtles that feed on the benthos [63]. Fibropapilloma tumors have been observed in fished green sea turtles in Bahia Hondita, in northeastern Guajira. Copper, lead, and other chemicals clogged into seagrass meadows can be consumed by sea turtles, bioaccumulate in their fat and body tissues, generate oxidative stress, and trigger tumor formation [64,65]. Pollutants may reach Guajira's coastal waters carried by the Rio Rancheria, which has poor water quality because of multiple anthropogenic uses along its flow trajectory [62]. Additionally, little pollution monitoring occurs, and there is a lack of knowledge of pollution loading except for sediment and erosion into coastal waters with heavy rains. Coastal desertification and loss of vegetation can result in higher sedimentation rates in the future $[66,67]$. Desertification is one of the main threats in Guajira. Although caused by extended droughts and the hot climate conditions, it is enhanced by agriculture and livestock overgrazing the already depleted vegetation [68]. Therefore, we consider agriculture and farming a threat of medium level to Guajira's biodiversity. Desertic soils in coastal areas cannot sustain biodiversity nor stop pollutants from entering the ocean. Desertification and water scarcity in Guajira can be enhanced by current global climate change [69]. The warming of seawater due to climate change is a high threat to Guajira's biodiversity; it can disrupt fish and other biota's physiological and reproductive cycles, reduce primary productivity, cause bleaching of coral reefs, discourage mutualisms, among others [69,70].

Another category of medium-level threat to species in Guajira is overharvesting, mainly overfishing. Many fish stocks were locally overfished in the past until the 20th century by commercial fisheries [7]. Currently, fishing operations are more artisanal, yet species of sea turtles and sharks, highly valued for consumption and commerce, are being targeted during fishing operations $[7,12]$. Some of these species are vulnerable or threatened with extinction (e.g., green sea turtle and Caribbean sharpnose shark). Even low harvesting levels of these species can contribute to their extinction [71]. Fishing pressure upon these species and others may increase as the climate warms and other extreme environmental conditions hinder additional traditional economic activities (e.g., livestock farming) [13] Fishing is poorly regulated or enforced in Guajira; therefore, it may become a greater threat for targeted marine species than it currently is.

\section{Strategies for Conservation and Management of Guajira's Coastal Environments}

Guajira's coasts' incredible habitats and biodiversity can be protected in several ways. Establishing or enlarging already established marine protected areas is a traditional biological conservation measure with high success [72,73]. This measure guarantees that segments of ecosystems or populations representative of the biodiversity of an area are protected, usually from several threats, particularly overharvesting or overfishing [74]. Guajira peninsula has one national park (Bahia Portete-Kaurrele) designed to protect strategic marine ecosystems of a bay area located in the northeast, including seagrass meadows and mangrove forests [75]. However, protecting areas falls short of conserving Guajira's biodiversity from other high threats, such as extreme weather, pollution, mining, and transportation (see Table 3). To address these threats, additional approaches that work with local, regional, and national human communities on different aspects, including socioeconomic, policy, health, education, are necessary.

One focus should be local peoples' economic welfare, so pressure upon and misuse of natural resources (fish, other species, water, soil, etc.) can be reduced. One instance is through the location of alternative sources of income to agriculture, livestock farming, and fishing. Some feasible alternatives include wind energy plants, tourism, sustainable algae mariculture [11,76-78]. Local community governance and management of coastal areas and resources are necessary. This includes empowering local communities in the monitoring 
of species and ecosystems health, water quality, soil quality, and air quality, etc. [79]. Additionally, government institutions for the environment should aggressively address the water scarcity and pollution problem throughout Guajira [62]. This involves water use and clean-up law enforcement to mining and agriculture companies, the identification and closure of land-based sources of pollution [60], the restoration of the Rancheria River and its tributaries, along with estuaries and mangrove ecosystems that are natural water filters [60], and the implementation of water purification plans. Additionally, soil restoration with the reforestation of plant cover is required in many areas of mid and upper Guajira, although it may naturally occur as water scarcity problems are addressed in several areas.

Increasing knowledge and awareness of the unique and magnificent marine coastal ecosystems of Guajira is an important component for its protection because strategies planning is informed, and thus, has a greater likelihood to succeed. There are entire ecological communities, taxonomic groups, species, and habitats still to be explored and understood in the coastal upwelled system of the Guajira peninsula. The task of studying and knowing this diversity is difficult due to its geographic, weather, and marine conditions, which constrain the study and conservation infrastructure. However, it is a must-do before this biodiversity vanishes. With the lead and participation of the local communities, and adequate funding support, new, alternative techniques for the exploration, management, and use of Guajira can be used to accomplish this task.

\section{Conclusions and Recommendations}

The nutrient-enriched waters of Guajira's upwelling are a complex environment driving coastal biodiversity. The unique coastal geomorphology and oceanography of the Guajira peninsula create a mosaic of shoreline, benthic, and water column communities that are only partially documented and described for species assemblages. Charismatic taxa groups, such as sharks and turtles, thrive in coastal Guajira, utilizing this area for juvenile recruitment and feeding. Yet this ecosystem is threatened by anthropogenic actions and, most immediately, by climate change. Several actions are recommended to manage the threats to Guajira's coastal biodiversity, including economic empowerment and alternatives for local communities. Local communities can be more intimately involved in natural resource management and restoration. However, national attention is needed in the enforcement of environmental laws in mining and agriculture practices.

Future research should focus on several taxonomic groups which presence and habitat use in Guajira is unknown. These include benthic and planktonic invertebrate animals, pelagic fishes, and seabirds. Other knowledge gaps about the biodiversity of coastal Guajira are the estimates of populations of key species, use of the area by migratory species, and overall fishing pressure on vulnerable species. There is an important gap in genetic diversity studies of Guajira's fauna; some information suggests the coastal geography and oceanography seem to favor genetic differentiation and connectivity in the Caribbean Sea, which place it as a focal point for these types of studies.

Author Contributions: Both authors contributed to the literature search, analysis, and interpretation of this review manuscript. Both authors wrote this manuscript and agreed to the published version of the manuscript. Both authors have read and agreed to the published version of the manuscript.

Funding: We thank our funding institutions Waitt Foundation, National Geographic, and Colciencias, Colombia.

Acknowledgments: We thank Jacob Patus for his collaboration with GIS for mapping biotopes. We thank the University of Miami, specifically the Biology Department, for supporting the publication of this review article. We thank the Wayuu communities of eastern Guajira for their immense collaboration with the authors when visiting and during fieldwork in their territories. We also thank Conservational International Colombia for logistical collaboration with the authors in the field when collecting some of the data presented here.

Conflicts of Interest: The authors declare no conflict of interest. 


\section{References}

1. Spalding, M.D.; Fox, H.E.; Allen, G.R.; Davidson, N.; Ferdaña, Z.A.; Finlayson, M.; Halpern, B.S.; Jorge, M.A.; Lombana, A.; Lourie, S.A.; et al. Marine Ecoregions of the World: A Bioregionalization of Coastal and Shelf Areas. BioScience 2007, 57, 573-583. [CrossRef]

2. Sullivan-Sealey, K.; Bustamante, G. Setting Geographic Priorities for Marine Conservation in Latin America and the Caribbean; The Nature Conservancy: Arlington, VA, USA, 1999.

3. Burke, L.; Maidens, J. Reefs at Risk in the Caribbean; World Resources Institute: Washington, DC, USA, 2004.

4. Miloslavich, P.; Díaz, J.M.; Klein, E.; Alvarado, J.J.; Díaz, C.; Gobin, J.; Escobar-Briones, E.; Cruz-Motta, J.J.; Weil, E.; Cortes, J. Marine biodiversity in the Caribbean: Regional estimates and distribution patterns. PLoS ONE 2010, 5, e11916. [CrossRef]

5. Rueda-Roa, D.T.; Muller-Karger, F.E. The southern Caribbean upwelling system: Sea surface temperature, wind forcing and chlorophyll concentration patterns. Deep Sea Res. Part I Oceanogr. Res. Pap. 2013, 78, 102-114. [CrossRef]

6. Siung-Chang, A. A review of marine pollution issues in the Caribbean. Environ. Geochem. Health 1997, 19, 45-55. [CrossRef]

7. Jackson, J.B.; Kirby, M.X.; Berger, W.H.; Bjorndal, K.A.; Botsford, L.W.; Bourque, B.J.; Bradbury, R.H.; Cooke, R.; Erlandson, J.; Estes, J.A. Historical overfishing and the recent collapse of coastal ecosystems. Science 2001, 293, 629-637. [CrossRef] [PubMed]

8. Cramer, K.L. History of human occupation and environmental change in western and central Caribbean Panama. Bull. Mar. Sci. 2013, 89, 955-982. [CrossRef]

9. Rogers, C.S.; Beets, J. Degradation of marine ecosystems and decline of fishery resources in marine protected areas in the US Virgin Islands. Environ. Conserv. 2001, 28, 312-322. [CrossRef]

10. Criales-Hernández, M.I.; García, C.B.; Wolff, M. Flujos de biomasa y estructura de un ecosistema de surgencia tropical en La Guajira, Caribe colombiano. Rev. Biol. Trop. 2006, 54, 1257-1282. [CrossRef] [PubMed]

11. Instituto de Investigaciones Marinas y Costeras José Benito Vives De Andréis and Corpoguajira. Atlas Marino Costero de La Guajira; Serie de Publicaciones Especiales de Invemar: Santa Marta, Colombia, 2012; p. 188.

12. Viloria Maestre, E.; Santos Acevedo, M.; Chávez Zabaleta, S.; Romero Arenas, J.A. Pesquería Artesanal del Margen Costero Entre Los Cocos (Magdalena) y Punta Gallinas (La Guajira), Caribe Colombiano; Instituto de Investigaciones Marinas y Costeras José Benito Vives De Andréis: Santa Marta, Colombia, 2016; p. 60.

13. Vásquez-Carrillo, C.; Peláez-Ossa, M. Insights into the ecology of sea turtles and the fisheries of eastern Guajira from the traditional knowledge of fishermen. Fish. Res. 2021, 238, 105915. [CrossRef]

14. IDEAM. Mapa Nacional de Degradación de Suelos por Salinización. 2017. Available online: http://www.ideam.gov.co/web/ ecosistemas/monitoreo-seguimiento-estado-calidad-suelos/-/document_library_display/9mDFEmPPfxAk/view/95764901 (accessed on 30 May 2021).

15. DANE. Censo Nacional de Población y Vivienda (CNPV) de Colombia. 2018. Available online: https://www.dane.gov.co/index php/estadisticas-por-tema/demografia-y-poblacion/censo-nacional-de-poblacion-y-vivenda-2018 (accessed on 1 May 2021).

16. Díaz Merlano, J.M.; Barrios Suárez, L.M.; Gómez-López, D.I. Las Praderas de Pastos Marinos en Colombia: Estructura y Distribución de un Ecosistema Estratégico; Serie Publicaciones Especiales; Instituto de Investigaciones Marinas y Costeras José Benito Vives De Andréis Invemar: Santa Marta, Colombia, 2003; p. 160.

17. Albis Salas, M.R.; Gómez-López, D.I.; Duque, G. Estructura de las praderas de Thalassia testudinum en un gradiente de profundidad en La Guajira, Caribe colombiano. Bol. Investig. Mar. Costeras-INVEMAR 2010, 39, 381-395. [CrossRef]

18. Chasqui, L.; Nieto, R.; Rodríguez-Rincón, A.; Gil-Agudelo, D.L. Ambientes marinos de la plataforma somera de la Guajira, Caribe Colombiano. Bol. Investig. Mar. Costeras 2013, 42, 2. [CrossRef]

19. Federal Geographic Data Committee (FGDC). Coastal and Marine Ecological Classification Standard (CMECS); NOAA: Reston, VA, USA, 2012.

20. Posada Posada, B.O.; Henao Pineda, W. Diagnóstico de la Erosión en la Zona Costera del Caribe Colombiano; Instituto de Investigaciones Marinas y Costeras-INVEMAR: Santa Marta, Colombia, 2008.

21. Vasquez-Carrillo, C.; Sullivan Sealey, K. Diversity and extent of coastal submerged aquatic vegetation in an unexplored coastal upwelling region of the Caribbean Sea. Int. J. Biodivers. Endanger. Species 2018, 2018. [CrossRef]

22. Díaz-Pulido, G. Vegetación marina de un sector de la plataforma continental de la Guajira (Caribe colombiano). Bol. Investig. Mar. Costeras 2000, 29, 27-34.

23. Avellaneda, W.J.B.; Patiño, E.A.; Guerra, M.L.; Gouriyu, W.A. New evidence of nesting Dermochelys coriacea (Tortuga Achepa) at Iporoimao-Utareo Beaches, Guajira, Colombia. Mar. Turt. Newsl. 2013, 13, 13-14.

24. Diaz-Pulido, G.; Garzón-Ferreira, J. Seasonality in algal assemblages on upwelling-influenced coral reefs in the Colombian Caribbean. Bot. Mar. 2002, 45, 284-292. [CrossRef]

25. Morales-Rozo, A. Monitoreo de Aves Migratorias y Residentes en Siete Humedales de La Guajira, Colombia. In Memorias II Congreso de Ornitología Colombiana; 2006. Available online: http:/ / corpoguajira.gov.co/wp/wp-content/uploads/2017/07/AVESCosteras.pdf (accessed on 5 August 2021).

26. Ceballos-Fonseca, C. Distribución de playas de anidación y áreas de alimentación de tortugas marinas y sus amenazas en el Caribe colombiano. Bol. Investig. Mar. Costeras 2004, 33, 79-99.

27. Vásquez-Carrillo, C.; Noriega-Hoyos, C.L.; Hernandez-Rivera, L.; Jáuregui-Romero, G.A.; Sullivan Sealey, K. Genetic Diversity and Demographic Connectivity of Atlantic Green Sea Turtles at Foraging Grounds in Northeastern Colombia, Caribbean Sea. Front. Mar. Sci. 2020, 7, 96. [CrossRef] 
28. Puentes, V.; Navia, A.F.; Falla, P.A.M.; Caldas, J.P.; Diazgranados, M.C.; Padilla, L.A.Z. (Eds.) Avances en el Conocimiento de Tiburones, Rayas y Quimeras de Colombia; Cross Market Ltda.: Bogotá, Colombia, 2009; 245p.

29. Lozano-Duque, Y.; Vidal, L.A.; Navas, S.G.R. La Comunidad Fitoplanctonica en el Mar Caribe Colombiano. In Biodiversidad del Margen Continental del Caribe Colombiano; Navas, G., Segura-Quintero, C., Garrido-Linares, M., Benavides-Serrato, M., Alonso, D., Eds.; Instituto de Investigaciones Marinas y Costeras Invemar: Santa Marta, Colombia, 2010; p. 458.

30. Urrego-Salinas, M.P.; Peña-Quevedo, H.; Dueñas-Valderrama, F. Equinodermos del Cabo de la Vela (La Guajira, Colombia) enla colección de referencia de la Universidad El Bosque. Biota Colomb. 2016, 17, 124-130. [CrossRef]

31. Díaz, M.; Zea, S. Distribución de esponjas sobre la plataforma continental de La Guajira, Caribe colombiano. Bol. Investig. Mar. Costeras-INVEMAR 2008, 37, 27-43. [CrossRef]

32. Polanco, A.; Quintero-Gil, J.A.; Cortés, F.; Duque, G. Contribución al conocimiento de la fauna íctica en dos isóbatas (10 y 50 m) de la región de La Guajira, Caribe colombiano. Bol. Investig. Mar. Costeras 2009, 38, 145-163. [CrossRef]

33. Almanza-Bernal, M. Análisis Genético Poblacional del Tiburón Cazón Antillano, Rhizoprionodon Porosus (Carcharhinidae), en el Caribe Colombiano; Universidad Nacional de Colombia-Sede Caribe: Santa Marta, Colombia, 2014; p. 62.

34. Carlson, J.; Charvet, P.; Avalos, C.; Briones Bell-lloch, A.; Cardenosa, D.; Espinoza, E.; Morales-Saldaña, J.M.; Naranjo-Elizondo, B.; Pacoureau, N.; Pilar Blasco, M.; et al. Rhizoprionodon porosus. IUCN Red List Threat. Species 2021. [CrossRef]

35. Carlson, J.K.; Heupel, M.R.; Bethea, D.M.; Hollensead, L.D. Coastal habitat use and residency of juvenile Atlantic sharpnose sharks (Rhizoprionodon terraenovae). Estuaries Coasts 2008, 31, 931-940. [CrossRef]

36. Pabón-Quintero, P.E. Estructura genética de las poblaciones de dos especies de haemúlidos (Haemulon aurolineatumy Haemulon steindachneri) en el Caribe colombiano. In Institutio de Estudios de Ciecias del Mar CECIMAR—Sede Caribe; Universidad Nacional de Colombia: Santa Marta, Colombia, 2016; p. 74.

37. Boström, C.; Pittman, S.J.; Simenstad, C.; Kneib, R.T. Seascape ecology of coastal biogenic habitats: Advances, gaps, and challenges. Mar. Ecol. Prog. Ser. 2011, 427, 191-217. [CrossRef]

38. Andrade, C.A.; Barton, E.D. The Guajira upwelling system. Cont. Shelf Res. 2005, 25, 1003-1022. [CrossRef]

39. Muller-Karger, F.E.; Castro, R.A. Mesoscale processes affecting phytoplankton abundance in the southern Caribbean Sea. Cont. Shelf Res. 1994, 14, 199-221. [CrossRef]

40. Gilbes, F.; Armstrong, R.A. Phytoplankton dynamics in the eastern Caribbean Sea as detected with space remote sensing. Int. J. Remote Sens. 2004, 25, 1449-1453. [CrossRef]

41. Chollett, I.; Mumby, P.J.; Müller-Karger, F.E.; Hu, C. Physical environments of the Caribbean Sea. Limnol. Oceanogr. 2012, 57, 1233-1244. [CrossRef]

42. Correa-Ramirez, M.; Rodriguez-Santana, Á.; Ricaurte-Villota, C.; Paramo, J. The Southern Caribbean upwelling system off Colombia: Water masses and mixing processes. Deep Sea Res. Part I Oceanogr. Res. Pap. 2020, 155, 103145. [CrossRef]

43. Waide, R.; Willig, M.; Steiner, C.; Mittelbach, G.; Gough, L.; Dodson, S.; Juday, G.; Parmenter, R. The relationship between productivity and species richness. Annu. Rev. Ecol. Syst. 1999, 30, 257-300. [CrossRef]

44. Paramo, J.; Quiñones, R.A.; Ramirez, A.; Wiff, R. Relationship between abundance of small pelagic fishes and environmental factors in the Colombian Caribbean Sea: An analysis based on hydroacoustic information. Aquat. Living Resour. 2003, 16, 239-245. [CrossRef]

45. Bakun, A. Patterns in the Ocean: Ocean Processes and Marine Population Dynamics; California Sea Grant, in Cooperation with Centro de Investigaciones Biologicas del Noroeste: La Paz, Mexico, 1996.

46. Hayes, D.B.; Ferreri, C.P.; Taylor, W.W. Linking fish habitat to their population dynamics. Can. J. Fish. Aquat. Sci. 1996, 53, 383-390. [CrossRef]

47. Wiegand, T.; Revilla, E.; Moloney, K.A. Effects of habitat loss and fragmentation on population dynamics. Conserv. Biol. 2005, 19, 108-121. [CrossRef]

48. Lutz, P.L.; Musick, J.A.; Wyneken, J. The Biology of Sea Turtles; CRC Press: Boca Raton, FL, USA, 2002.

49. Meylan, P.A.; Meylan, A.B.; Gray, J.A. The Ecology and Migrations of Sea Turtles 8. Tests of the Developmental Habitat Hypothesis. Bull. Am. Mus. Nat. Hist. 2011, 357, 1-70. [CrossRef]

50. Bass, A.L.; Lagueux, C.J.; Bowen, B.W. Origin of green turtles, Chelonia mydas, at "Sleeping Rocks" off the northeast coast of Nicaragua. Copeia 1998, 1998, 1064-1069. [CrossRef]

51. Makowski, C.; Seminoff, J.A.; Salmon, M. Home range and habitat use of juvenile Atlantic green turtles (Chelonia mydas L.) on shallow reef habitats in Palm Beach, Florida, USA. Mar. Biol. 2005, 148, 1167-1179. [CrossRef]

52. Navas, G.; Segura-Quintero, C.; Garrido-Linares, M.; Benavides-Serrato, M.; Alonso, D. Biodiversidad del Margen Continental del Caribe Colombiano; Serie de Publicaciones Especiales; Invemar: Santa Marta, Colombia, 2010; p. 458.

53. Martínez, M.L.; Intralawan, A.; Vázquez, G.; Pérez-Maqueo, O.; Sutton, P.; Landgrave, R. The coasts of our world: Ecological, economic and social importance. Ecol. Econ. 2007, 63, 254-272. [CrossRef]

54. Crain, C.M.; Halpern, B.S.; Beck, M.W.; Kappel, C.V. Understanding and managing human threats to the coastal marine environment. Ann. N. Y. Acad. Sci. 2009, 1162, 39-62. [CrossRef]

55. Pawar, P.R.; Shirgaonkar, S.S.; Patil, R.B. Plastic marine debris: Sources, distribution and impacts on coastal and ocean biodiversity. PENCIL Publ. Biol. Sci. 2016, 3, 40-54.

56. Ellison, A.M.; Farnsworth, E.J. Anthropogenic disturbance of Caribbean mangrove ecosystems: Past impacts, present trends, and future predictions. Biotropica 1996, 28, 549-565. [CrossRef] 
57. Dahlgren, C.P.; Kellison, G.T.; Adams, A.J.; Gillanders, B.M.; Kendall, M.S.; Layman, C.A.; Ley, J.A.; Nagelkerken, I.; Serafy, J.E. Marine nurseries and effective juvenile habitats: Concepts and applications. Mar. Ecol. Prog. Ser. 2006, 312, 291-295. [CrossRef]

58. Gracia, A.; Medellín-Mora, J.; Gil-Agudelo, D.L.; Puentes, V. (Eds.) Guía de las especies introducidas marinas y costeras de Colombia; Serie de Publicaciones Especiales del Invemar No. 23; Instituto de Investigaciones Marinas y Costeras (Invemar) y Ministerio de Ambiente y Desarrollo Sostenible: Bogotá, Colombia, 2011; p. 136.

59. Marín-Guirao, L.; Lloret, J.; Marin, A. Carbon and nitrogen stable isotopes and metal concentration in food webs from a mining-impacted coastal lagoon. Sci. Total Environ. 2008, 393, 118-130. [CrossRef] [PubMed]

60. Mensah, A.K.; Mahiri, I.O.; Owusu, O.; Mireku, O.D.; Wireko, I.; Kissi, E.A. Environmental impacts of mining: A study of mining communities in Ghana. Appl. Ecol. Environ. Sci. 2015, 3, 81-94.

61. Olivares, H.G.; Lagos, N.M.; Gutierrez, C.J.; Kittelsen, R.C.; Valenzuela, G.L.; Lillo, M.E.H. Assessment oxidative stress biomarkers and metal bioaccumulation in macroalgae from coastal areas with mining activities in Chile. Environ. Monit. Assess. 2016, 188, 25. [CrossRef]

62. Doria Argumedo, C.; Deluque Viloria, H. Niveles y distribución de metales pesados en el agua de la zona de playa de Riohacha, La Guajira, Colombia. Rev. Investig. Agrar. Ambient. 2015, 6, 123-131. [CrossRef]

63. Vasquez-Carrillo, C. Role of an Upwelled Coastal Area in Northeastern Colombia in the Distribution, Population Dynamics and Genetic Diversity of the Migratory Habitat-Shifting Chelonia Mydas. Ph.D. Thesis, University of Miami, Coral Gables, FL, USA, 2017; p. 128.

64. Guimaraes dos Santos, R.G.; Silva Martins, A.S.; Torezani, E.; Baptistotte, C.; da Nóbrega Farias, J.; Antunes Horta, P.A.; Work, T.M.; Balazs, G.H. Relationship between fibropapillomatosis and environmental quality: A case study with Chelonia mydas off Brazil. Dis. Aquat. Org. 2010, 89, 87-95. [CrossRef]

65. da Silva, C.C.; Klein, R.D.; Barcarolli, I.F.; Bianchini, A. Metal contamination as a possible etiology of fibropapillomatosis in juvenile female green sea turtles Chelonia mydas from the southern Atlantic Ocean. Aquat. Toxicol. 2016, 170, 42-51. [CrossRef] [PubMed]

66. Vanmaercke, M.; Poesen, J.; Maetens, W.; de Vente, J.; Verstraeten, G. Sediment yield as a desertification risk indicator. Sci. Total Environ. 2011, 409, 1715-1725. [CrossRef] [PubMed]

67. Restrepo, J.D.; Kettner, A.J.; Syvitski, J.P. Recent deforestation causes rapid increase in river sediment load in the Colombian Andes. Anthropocene 2015, 10, 13-28. [CrossRef]

68. Middleton, N. Rangeland management and climate hazards in drylands: Dust storms, desertification and the overgrazing debate. Nat. Hazards 2018, 92, 57-70. [CrossRef]

69. Doney, S.C.; Ruckelshaus, M.; Duffy, J.E.; Barry, J.P.; Chan, F.; English, C.A.; Galindo, H.M.; Grebmeier, J.M.; Hollowed, A.B.; Knowlton, N. Climate change impacts on marine ecosystems. Annu. Rev. Mar. Sci. 2012, 4, 11-37. [CrossRef] [PubMed]

70. Taylor, G.T.; Muller-Karger, F.E.; Thunell, R.C.; Scranton, M.I.; Astor, Y.; Varela, R.; Ghinaglia, L.T.; Lorenzoni, L.; Fanning, K.A.; Hameed, S.; et al. Ecosystem responses in the southern Caribbean Sea to global climate change. Proc. Natl. Acad. Sci. USA 2012, 109, 19315-19320. [CrossRef] [PubMed]

71. Lacy, R.C. Considering threats to the viability of small populations using individual-based models. Ecol. Bull. $2000,48,39-51$.

72. Edgar, G.J.; Stuart-Smith, R.D.; Willis, T.J.; Kininmonth, S.; Baker, S.C.; Banks, S.; Barrett, N.S.; Becerro, M.A.; Bernard, A.T.; Berkhout, J.; et al. Global conservation outcomes depend on marine protected areas with five key features. Nature 2014, 506, 216-220. [CrossRef] [PubMed]

73. Ban, N.C.; Gurney, G.G.; Marshall, N.A.; Whitney, C.K.; Mills, M.; Gelcich, S.; Bennett, N.J.; Meehan, M.C.; Butler, C.; Ban, S.; et al. Well-being outcomes of marine protected areas. Nat. Sustain. 2019, 2, 524-532. [CrossRef]

74. Agardy, T. Effects of fisheries on marine ecosystems: A conservationist's perspective. ICES J. Mar. Sci. 2000, 57, 761-765. [CrossRef]

75. Gutiérrez-Moreno, C.; Alonso, C.D.; Segura-Quintero, C. Diseño de un area marina protegida para Bahía Portete-La Guajira, Caribe Colombiano. Bol. Investig. Mar. Costeras 2008, 37, 198-212. [CrossRef]

76. Delgadillo-Garzón, O.; Newmark, F. Pilot culture of red seaweeds (Rhodophyta) in Portete Bay, La Guajira, Colombia P. Boletín Investig. Mar. Costeras-INVEMAR 2008, 37, 7-26.

77. León, R.R.; Tirado, D.A.M. Aspectos técnicos y económicos para el establecimiento comercial del maricultivo de algas en Colombia: Experiencias en la Península de La Guajira. Ambiente Desarro. 2011, 15, 123-144.

78. Carvajal-Romo, G.; Valderrama-Mendoza, M.; Rodríguez-Urrego, D.; Rodríguez-Urrego, L. Assessment of solar and wind energy potential in La Guajira, Colombia: Current status, and future prospects. Sustain. Energy Technol. Assess. 2019, $36,100531$. [CrossRef]

79. Wali, A.; Alvira, D.; Tallman, P.; Ravikumar, A.; Macedo, M. A new approach to conservation: Using community empowerment for sustainable well-being. Ecol. Soc. 2017, 22, 6. [CrossRef] 